\title{
Occupation of Racial Grief, Loss as a Resource: Learning From 'The Combahee River Collective Black Feminist Statement'
}

\author{
Suryia Nayak ${ }^{1}$
}

Received: 1 June 2018/ Accepted: 1 July 2019/Published online: 17 September 2019

(C) The Author(s) 2019

\begin{abstract}
The methodology of 'occupation' through rereading The Combahee River Collective Black Feminist Statement (The Combahee River Collective, in: James, Sharpley-Whiting (eds) The Black Feminist Reader. Blackwell Publishers Ltd., Oxford, pp 261-270, 1977) demonstrates the necessity of temporal linkages to historical Black feminist texts and the wisdom of Black feminist situated knowers. This paper argues that racism produces grief and loss and as long as there is racism, we all remain in racial grief and loss. However, in stark contrast to the configuration of racial grief and loss as something to get over, perhaps grief and loss can be thought about differently, for example, in terms of racial grief and loss as a resource. This paper questions Western Eurocentric paternalistic responses to Black women's 'talk about their feelings of craziness... [under] patriarchal rule' (The Combahee River Collective 1977: 262) and suggests alternative ways of thinking about the psychological impact of grief and loss in the context of racism. In this paper, a Black feminist occupation of racial grief and loss includes the act of residing within, and the act of working with the constituent elements of racial grief and loss. The proposal is that an occupation of racial grief and loss is a paradoxical catalyst for building a twenty-first century global intersectional Black feminist movement.
\end{abstract}

Keywords Intersectionality - Racial grief - Combahee . Loss $\cdot$ Feminism

Suryia Nayak

s.nayak@salford.ac.uk

1 School of Health and Society, University of Salford, Salford M6 6PU, UK

\section{Introduction}

Premised on the critical political framework of the activism of Black feminism with particular reference to The Combahee River Collective, this paper argues for the occupation of inherent tensions within grief and loss. More particularly, the focus is on the racial grief of Black women, who because of the colour of their skin are subject to racism under global regimes of white supremacy; the belief, theory, or doctrine that white people are inherently superior to people from all other racial groups. KeeangaYamahtta Taylor explains that The Combahee River Collective "was important because of its internationalism... as part of a global movement... in the struggle against the colonial, imperialist and capitalist domination of the West... One can see the importance of international solidarity and identification especially today, when the United states so readily uses the abuse of women in other countries, such as Afghanistan as a pretext for military intervention' (Taylor, 2017: 12). Here, Taylor points to the contemporary relevance of The Combahee River Collective, which was formed in 1974, and furthermore, Taylor points to importance of 'solidarity'. Throughout this paper, the idea of solidarity, collective and communal connection is proposed in the face of disconnection, fragmentation and division.

The argument presented is that racial grief is a symptom of living in the context of a racist world; thus, the emphasis is on grief as a product of context. More specifically, the root of racial grief lies in contexts where disconnection, fragmentation and division are dominant. In summary, racism is constituted by and contingent upon disconnection, fragmentation and division and a reaction to living in such a context is racial grief. An understanding of how and why racial grief is a product of the context of racism and 
can be used to challenge racism is foundational to the therapeutic political activism of anti-racist, anti-colonial feminism. Thus, the critical political framework of the activism of Black feminism, which is a framework of antiracist, anti-colonial theory is useful for anyone, regardless of their identity, who wishes to understand and apply antiracist, anti-colonial thinking in their lives generally and specifically in their actions for social justice and in their clinical practices. In short, the activism of Black feminism is for everyone in all situations because in the situation where 'racist social structures create racist psychic structures' (Oliver, 2001: 34), the logic is that 'we all live in a racist society; racism shapes our identity and makes us all racist subjects' (Nayak, 2015: 51). The idea that we are 'all racist subjects' is a profoundly difficult but important idea if racism is to be confronted. Audre Lorde explains that, 'the true focus of revolutionary change is never merely the oppressive situations which we seek to escape, but that piece of the oppressor which is planted deep within each of us, and which knows only of the oppressors' tactics, the oppressors' relationships' (Lorde, 1980: 123). It could be argued that grief, loss, fragmentation and disconnection are characteristics of 'the oppressors' tactics, the oppressors' relationships'. Thus, 'revolutionary change' for the dismantling of racism requires an understanding and reformulation of grief, loss, fragmentation and disconnection. In this paper, the reformulation, proposed, is based on a close re-reading of The Combahee River Collective Black Feminist Statement (1977).

\section{The Dialectic of Racial Grief}

This paper tracks the ways in which the actions and analysis described by The Combahee River Collective are conditional upon loss, fragmentation, disconnection, linkages and collectivism. The proposal is that racial grief is a resource rather than a hindrance for the transformation of fragmentation to integration. The framing of grief as a resource is a radical departure from traditional conceptualizations of grief and loss that lead to clinical interventions that seek to resolve or mitigate the effects of grief and loss. In other words, the idea of grief and loss as an experience that can be useful departs from the framing of grief and loss as a pathological state requiring a remedy. Being in a state of grief and loss is at the very least uncomfortable and can feel unbearable leading to a wish to evacuate these feelings. Thus, the messages articulated in this paper, based primarily on the idea that as long as there is racism there is loss, is a difficult message to incorporate. The message is difficult on an emotional and intellectual level, because the idea that racial grief can be used as a resource to challenge the causes of racial grief is dialectic.
The dialectic that the very conditions that give birth to grief and loss, for example the social conditions of racism, are the same very conditions that anti-racist, anti-colonial feminist activism is directed against (Hill Collins, 2000: 3; Fox Piven \& Cloward, 1979: x). However, shifting the analysis from grief and loss as something to fix or in need of mending, to an analysis of grief and loss as a resource, opens up a window of opportunity for re-thinking, reconfiguring and re-claiming the experience of grief and loss so that the emotional energy of grief and loss can be recognized and utilized as a force to challenge the oppressive social structures that are at the root of so many interconnected losses. In keeping with the frame of grief and loss as a resource, this paper insists that psycho-social approaches need to be vigilant not to replicate the fragmentation they seek to treat, in regard to the causes, manifestations and transformation of Black women's fragmentation, disconnection and disintegration.

\section{What it Means to Occupy Racial Grief}

Foundational to the argument proposed is the idea of occupying or the occupation of racial grief. To occupy something means to live, reside, lodge or dwell somewhere and to be occupied with something means to be busy or working with something. Thus, the idea of occupying racial grief is to recognize that living within racism produces loss and grief; racial grief is a symptom of living within the context of racism. The idea of being occupied with the grief of racism or the occupation of racial grief suggests the idea of being busy or being at work/working with the grief that racism produces. However, rather than being busy in the work of getting rid of the grief that racism causes, an alternative idea is to be occupied or busy in the work of understanding how racial grief can be harnessed as a force for collective action directed against the multiple interconnected social injustices of racism.

The etymology of 'occupation' from the Latin word occupare, in the fourteenth century, came to mean 'take over', 'seize' and 'take into possession'. The word 'occupation' conjures up contemporary connotations of the seizure of a territory by military force and/or the act of squatting or taking over a habitat, as a gesture of protest. The idea of feminist 'occupation' as a methodology, conceptual framework and modality of intervention is not neutral and, as such, has an explicit political agenda. Here, the metaphor of 'occupation' is politically charged, because ' $[\mathrm{t}]$ here can, of course, be no apolitical scholarship' (Mohanty, 1984:19). In this paper, the use of occupation, both in relation to residence or inhabitancy and in relation to labour or habit, deliberately invokes the characteristic of insurrection and defiance. The refusal of Black 
women to acquiesce to psychopathologies of their racial grief, in favour of utilizing (through an occupation) their racial grief as a resource, to better understand it in terms of power and context is insurrection as empowerment. The argument presented is that engagement in the political activism of Black feminism is an alternative to traditional psychological modalities of therapeutic recovery in the transformation of fragmentation to integration.

This paper is a call for Black women to find the energy, determination and passion to share a collective, personal and relational dismantling of their racial grief in order to develop the conceptual tools required to scrutinize the 'psychic life of power' (Butler, 1997); it is a call to 'thinking the theory of power together with a theory of the psyche' (Butler, 1997:3). In this frame, thinking about racial grief is thought in relation to the unequal power relations of racism. However, as Barbara Smith (Smith, 2017: 64) explains, the goal of dismantling of oppression is not to gain more power, as this results in producing and reproducing loss, fragmentation, divisions and disconnections, instead, the goal of dismantling of oppression is justice. Having justice rather than power as the foundation and objective of anti-racist, anti-colonial feminist action is an example of having a conceptual foundation and goal centred on connection instead of fragmentation, because 'if it's a forward movement towards justice, you will see that people of different backgrounds and different places... come together' (Smith, 2017: 65).

This paper calls for examination of the conscious and unconscious psychological experience of racial grief, produced as a result of the psychic life of racism to be harnessed for healing and constructive change rather than harm. To be clear, this conceptual paper is a call to action, where action is constitutive of, and contingent upon, an analysis of the role that the 'psychic life' of oppression plays in fostering discursive practices of fragmentation that become experienced as inherent to a sense of self. Here, the traditional fragmentation or partition and between action and thinking, practice and epistemology or activism and theory are transgressed. Thus, the division between methodology and content becomes blurred to produce the idea of the mutually constitutive and contingent relationship between content (thinking/theory/epistemology/phenomenology) and method (action/activism/practice/ intervention/treatment). The co-productive relationship between method and content is demonstrated in the experience of The Combahee River Collective evidenced within their Black Feminist Statement (1977), which articulates the ways in which their racial grief functions as both a method (the catalyst for the formation of The Combahee River Collective) and the content of what they are doing and why (the basis of their mission for transformation).

\section{Reformulation of Fragmentation}

Reformulation of fragmentation performs a number of important shifts in thinking:

- A reformulation of the 'fragmented' self through shared Black feminist collective communal activity and activism shifts the emphasis from an individual to a relational model;

- A reformulation of the theoretical basis of fragmentation on the foundation of Black feminist thinking shifts the emphasis from an apparently neutral to an explicitly political model of women's empowerment;

- A reformulation of the 'fragmented' self in racial grief as located within the social context of racism shifts the emphasis from an individual-specific symptom to a context-specific symptom;

- A reformulation of the inherent inevitable tensions within the experience and utilization of racial grief in order to resist binary resolutions shifts the emphasis from neat solution focussed approaches to the occupation of tensions as a basis for transformation.

A reformulation of fragmentation, which is an aspect of racial grief, has the effect of creating opportunities to think differently about the act and idea of resistance to the effects and causes of racial grief. It is important to remember that resistance to oppression is a stage in the process towards transformation and not the end goal.

\section{Continually Building a Habitation}

Black feminist transformation requires that we 'must continually build a habitation for your ideas, your thoughts, and yourself' (Seshadri-Crooks, 2000: 373). Continually moving house is no easy task; it brings disruption, uncertainty and requires openness to new, unfamiliar and sometimes uncomfortable territory. It could be argued that The Combahee River Collective Black Feminist Statement is a reflective manifesto, which identifies the content of the task of 'continually building a habitation' for thinking about racial grief, and the method by which these challenges can be managed. The metaphor of "continually building a habitation' takes on increased complexity when juxtaposed with the metaphor of 'occupation'. It would seem that 'continually building a habitation' is at odds with the meaning of 'occupation' as a defiant 'seizing hold of' or insubordinate squatting and refusal to be (re)moved. However, the challenge of the task requires an intellectual and emotional tolerance of the dialectic of being in a persistent transition of continual construction of the self, whilst occupying, reoccupying and preoccupying a resolute commitment to social justice. It is the challenge of staying 
steadfast to principles of emancipation from oppression (invoked by the metaphor of 'occupation'), whilst not being shackled to particular ways of thinking (invoked by the metaphor 'continually building a habitation'). The work of 'continually building a habitation' is of remaining open to the contested, unstable, indeterminate position of all concepts, and the work of 'occupation' is of the refusal to be moved from the conviction to human rights, and of course, the concept of human rights is itself an unstable social construction. The word 'continually' points to the, individual, communal and societal, developmental process of building that will always remain a work in progress. Here, the notion of a developmental work in progress enables an approach to the building of emotional, intellectual, spiritual and political psycho-social habitations that have an eye to the long view. Too often, the experience of growth as nonlinear, slow and cumulative is translated into self-deprecating harshness that corrodes confidence, trust and progress.

Within the critical framework of the activism of Black feminism, the occupation of racial grief, including fragmentation, disintegration and disconnection, is the work of continually building a Black feminist habitation. Here, the metaphor of habitation, used as both a noun (place) and a verb (act of residing in a place) can refer to a cognitive, intellectual, philosophical body of knowledge or Black feminist epistemology, and, it can, simultaneously, refer to the psychological, emotional and mental landscape of the psyche. In this paper, a Black feminist habitation refers to the interdependent co-production of the psychological, the intellectual, the physical, the sociopolitical and the material. The work of continually building a Black feminist habitation needs to draw on the skills, experience and intelligence of the legacy of Black feminist architects of ideas; this legacy is a privileged resource. The racial grief of Black women has been, and will continue to be, instrumental in the architecture of an intersectional, international, Black feminist movement. However, the collective, connective power of a Black feminist women's liberation movement is dependent on linkages with, in contrast to fragmentation from, the historical legacy of Black feminist scholarship and activism. The Combahee River Collective Black Feminist Statement is an example of a group of Black feminists who were pioneering architects of the Black feminist movement: They were courageous, rigorous and able to use vulnerability as strength. Rereading of The Combahee River Collective Black Feminist Statement demonstrates its relevance for contemporary Black feminist movement builders, and the tensions, challenges and potential disappointments of such building work. The Combahee River Collective Black Feminist Statement demonstrates the potential of the racial grief of Black women to act as a catalyst for an intersectional feminist transformation on a personal, communal and international level. Keeanga-Yamahtta Taylor explains that, 'The Combahee River Collective (CRC) was a radical Black feminist organization formed in 1974 and named after Harriet Tubman's 1853 raid on the Combahee River in South Carolina that freed 750 enslaved people' (Taylor, 2017: 4). Thus, the formation and work of The Combahee River Collective makes an explicit connection with the activism of Black feminism over a century before their formation in 1974. The point is that this explicit connection with the legacy of Black feminism, embedded in the name The Combahee River Collective, is in itself a challenge to disconnections from the legacy inspiration and learning of anti-racist, anti-colonial activist struggles.

\section{Critical Political Framework of the Activism of Black Feminism: A Contestation of Fragmentation Approaches}

In terms of the structure, theory and political thrust of this paper, this re-reading of The Combahee River Collective Black Feminist Statement constitutes both the method (the how) and content (the what) that drives the key messages of the paper. In other words, this re-reading of The Combahee River Collective Black Feminist Statement is, in terms of method, an act of integrating the past with the present, whilst drawing on the content of The Combahee River Collective Black Feminist Statement as valuable insights in support of the arguments presented in this paper. Here, method and content are mutually constitutive and mutually contingent-there is no fragmentation in this integrated relation.

The transformation of fragmentation to integration, including the irresolvable tensions intrinsic to this process of transformation, is premised on the idea that Black women's racial grief is a psycho-social phenomenon of racism and as such needs to be located within a psychosocial analysis. There is nothing neutral or objective about the issue and experience of racism, and accordingly there is nothing neutral or objective in how grief, as a result of racism, is treated. This paper encourages consideration of the critical political instantiation of the activism of Black feminism because it provides an approach to Black women's racial grief that places power, position, voice and representation as pivotal to discursive practices that aim to transform fragmentation to integration.

Within the critical framework of the activism of Black feminism, the differentiation of the political from the theoretical and the methodological functions of language is a form of fragmentation that replicates intersubjective fragmentation. In other words, within the context of a 'man made language' (Spender, 1980) and in 'a language in 
which blackness is a sign of absence' (Gates, 1986:218), language produces and re-produces fragmented subjectivity. For example, the use of the word 'white' has become synonymous with lightness as a symbol of that which is 'good'; 'pure'; 'virginal'; and desired. In contrast, the word 'black' has become synonymous with darkness as a symbol of that which is 'bad; deviant; not to be desired'. The critical framework of the activism of Black feminism draws on and develops the notion of language functioning simultaneously on multiple interconnected dimensions in accord with Black literary and oral narrative traditions of integrated 'polyvoice' and 'polyrhythms' (Boyce Davies, 1994:23). The critical framework of the activism of Black feminism recognizes:

That there is a general social law, that this law is the symbolic dimension which is given in language and that every social practice offers a specific expression of that law. (Kristeva, 1973:25)

Thus, the critical framework of the activism of Black feminism takes the stance that any analysis of, and intervention in regard to, the 'social practices' of racism, which cause fragmentation, require an integrated, intersectional approach. In this Black feminist framework, the political, the theoretical and the methodological are mutually constitutive and contingent. Indeed, it could be argued that, in relation to the phenomenon of fragmentation, the critical framework of the activism of Black feminism is particularly apposite because of its contestation, and deconstruction of fragmenting border approaches. In accordance with the critical framework of the activism of Black feminism, the anti-colonial scholar Thiongo summarizes of the problem of borders in the following way:

if a border marks the outer edge of one region, it also marks the beginning of the next region. As the marker of an end, it also functions as the marker of a beginning. Without the end of one region, there can be no beginning of another. Depending on our starting point, the border is both the beginning and the outer edge. Each space is beyond the boundary of the other. The border in between serves as both the inner and the outer of the other. It is thus at once the boundary and a shared space. (Thiongo, 1996:120)

Indeed, the occupation of loss is an occupation of the 'border in between' or borderlands (Anzaldúa, 2007) of hybridity (Bhabha, 1994), in order to engage with 'undecidability that turns the discursive conditions of dominance into the grounds of intervention' (Bhabha, 1994:112). Here, the 'grounds of intervention' in relation to the grief of fragmentation, which arises from the conditions of racism, is the refusal of fragmentary, binary, split positions.
Within the critical framework of the activism of Black feminism, 'undecidability' is the grounds for integration.

\section{The Methodology of (Re)-Reading Black Feminist Texts as a Modality of Integration}

In stark contrast to fragmentation, the methodology of rereading Black feminist texts is a theoretical, political and methodological practice of linkage and connectivity. The argument presented here is that engagement with existing Black feminist texts and the creation of new Black feminist texts is a modality of (re)integration to counter the harm of fragmentation. Textual analysis and the act of working with the relationship between and through the weave of texts, or intertextuality, are fundamental to raising consciousness that represents a speaking out and breaking of silence, which are foundational to women's liberation. Here, women's liberation is seen as central to women's recovery from the injurious effects of fragmentation that result from living in social contexts of fragmentation. The methodology of re-reading, reading and producing Black feminist writing is a central to feminist activism and should be seen as a form of activism in its own right. In other words, the documentation, reflections, poetry, letters, emails, pamphlets, reports, constitutions and manifestos of Black feminism are not secondary to other Black feminist activist activities. Time has to be made to produce the text of activism and the excuse of tiredness, lack of resources or falling into the trap that some women can write and others cannot deprive Black women of their creative potential and the insights that come from contributing to the legacy of Black feminist scholarship. Indeed, to deprive Black women from producing Black feminist texts about their experiences of communal activism is to cause fragmentation on multiple levels, from the individual to the collective. The importance of Black women's collective shared reading and production of texts is documented in the text of The Combahee River Collective Black Feminist Statement:

We had always shared our reading with each other, and some of us had written papers on Black feminism for group discussion a few months before this decision was made. We began functioning as a study group and also began discussing the possibility of starting a Black feminist publication... Currently we are planning to gather together a collection of Black feminist writing. We feel that it is absolutely essential to demonstrate the reality of our politics to other Black women and believe that we can do this through writing and distributing our work. (1977:269) 
The act of explicitly referencing, naming and referring to Black feminist texts performs an active invocation of the power of connecting to Black women's voices that can be accessed even in times of isolation and aloneness. All feminist collective meetings, gatherings, rallies and gettogethers should include an element of (re)-reading, reading and perhaps producing Black feminist texts. Indeed, Black feminist texts should be a live feature of every aspect of all Black women's lives, because the intersectional experience of racism is live in all aspect of living.

\section{Racial Grief: A Catalyst for a Global Black Feminist Movement}

Racial grief is a reaction to the numerous intertwining losses, produced by racist social structures, including caste and class, resulting in loss of humanity and the fragmentation inherent to degradation. The Combahee River Collective Black Feminist Statement reports that, 'an early group member once said, "We are all damaged people merely by virtue of being Black women." We are dispossessed psychologically and on every other level' (1977: 266). Within psychology, psychoanalysis, social work and more broadly within society, grief and loss are something to get over; and the situation of not getting over the grief of loss is constructed as a pathology or maladaptation, for example in regard to melancholia (Freud, 1917). The construction of 'persistent grief as pathological' shadows the potential for the experience of loss and grief to be a catalyst for resilience, resistance and transformation. Herein lies a foundational premise of this paper, namely that the re-framing of racial melancholia from the category of psychological abnormality, in need of clinical treatment, to racial melancholia as a resource for the transformation of fragmentation to integration is a radical, alternative, empowerment approach. In short, the premise is that the fragmentation, disconnection and disintegration, experienced by women, subjugated in and through white supremacy can be a catalyst for connection, collaboration and bridge building. McIntosh (1988) provides an analysis of 'unpacking the knapsack of white privilege', which unpacks the ways in which those who do not enjoy such privileged experience fragmentation on a daily basis. In the frame of racial grief as a force for sociopolitical change, the implications for Black feminism liberation movements, within the context of, sociopolitical structures; discursive practices that are racist, transphobic, homophobic, patriarchal and capitalist are far reaching. To be clear, this phraseology is not intended to represent prevailing social orders in more-or-less monolithic terms. There is the specificity of each of these forms of oppression; for example, racism is not the same as sexism and neither are the same as transphobia or homophobia or profit and loss economy of capitalism. However, underlying all of these oppressive social constructions of social order is the idea that:

Institutionalised rejection of difference is an absolute necessity in a profit economy which needs outsiders as surplus people... as a result, those differences have been misnamed, and misused in the service of separation and confusion. (Lorde, 1980:115)

In other words, the sociopolitical and economic context of racism, transphobia, homophobia, patriarchy and capitalism causes fragmentation, separation and division on a global to local level, operating through the individual selfto macro-international structures. Drawing on the evidence of their lived experience, The Combahee River Collective Black Feminist Statement provides a clear explanation that these contextual forms of oppression are not lived in isolation from each other:

We believe that sexual politics under patriarchy is as pervasive in Black women's lives as are the politics of class and race. We also often find it difficult to separate race from class from sex oppression because in our lives they are most often experienced simultaneously. We know that there is such a thing as racial-sexual oppression which is neither solely racial nor solely sexual, e.g., the history of rape of Black women by white men as a weapon of political oppression (1977:264)

Any analysis of the causes of the harmful effects of psycho-social fragmentation should not replicate that fragmentation by forcing women's lived experience into clinical or sociological divisions. All analyses and interventions based on these analyses need to hold the goal of integration as central. Thus, any analysis or intervention in regard to the cause of and recovery from fragmentation, separation and division has to take account of the relationship of the individual to the contexts they are located in.

Within the activism of Black feminism, to confront the subjugation of women and girls, loss not only takes the form of the loss of bereavement due to death/loss of life, but also takes the form of the manifold and overlapping losses of economic, social, cultural, civil and political human rights, produced through oppression (Ahmed, 2010: 139). Spivak's question, 'can the subaltern speak?' (1988), is constituted and contingent upon loss. In the context of this paper, where the subaltern represents those subjugated by white supremacist hegemony, it could be argued that Spivak's question goes to the heart of the predicament of how the effects of the oppression of racism, namely racial 
grief, can be used for the transformation of fragmentation to integration. The question for the subaltern, is, how can anything (i.e. voice, position, representation) that is born of racism, including the effects of fragmentation as a product of racial grief, be a source of psycho-social integration? And, yet, this is exactly what this paper is arguing for, with the pivotal qualification that, it is by occupying the inevitable tensions that Spivak opens up in her seminal question (Can the Subaltern Speak?), rather than any neat resolution, that the energy, feeling and passion of racial grief can be utilized. This is a different approach to solution focussed, medicalized approaches based on treating fragmentation of the self as psychopathology. Spivak's question encapsulates the predicament described by Gates, ' $[\mathrm{t}]$ hey knew just how to keep us in our place. And the logic was breathtakingly simple: If you win, you lose' (Gates, Jr., 1992, cited in Minh-ha, 2011: 48). Here, Gates summarizes the paradox of loss, namely being caught in the inevitable simultaneous position of winning and losing that Black feminist responses to racial grief needs to occupy (in terms of residing in and working with). On the one hand, 'you win' in the occupation of loss as a force for the therapeutic effects of political mobilization, where loss becomes a binding glue of solidarity. For example, the women's international trade union movement was born out of, and is sustained by, women's shared experience of their loss of socio-economic employment rights. Similarly, the international Rape Crisis movement was born out of, and is sustained by, women's collective experiences of loss due to sexual violence. However, on the other hand, 'you lose', when the occupation of the loss that produced collective therapeutic political mobilization is also a force that threatens to undo that same collective therapeutic political mobilization. For example, in the situation whereby the psychological pain of loss configured along the lines of differences of class, caste, sexuality and social constructions of ability creates fragmentation. In the examples of the women's international trade union movement (International Trade Union Confederation https://www.ituc-csi.org/women, 196) and the international Rape Crisis movement (International Rape Crisis Hotlines, http://www.ibiblio.org/rcip/), the loss that brought women together to fight for social justice is also the very same loss that can produce spurious claims to who is more or less oppressed, based on, and thereby replicating, harmful fragmenting constructs of hierarchies of oppression (McDonald \& Coleman, 1999) that 'keep us in our place' (Gates, Jr., 1992, cited in Minh-ha, 2011: 48).

In regard to the collective mobilization of Black feminist movements to end all forms of violence against women and girls, this paper calls for the occupation of loss, where occupation simultaneously includes the idea of residence (as into occupy a place) and the idea of work (as being occupied with a task) (Cheng, 2001). The question of the psychological nature of fragmentation and move to integration is a psycho-social political matter and cannot be reduced to a category or phenomenon of clinical psychology. Thus, the call that this paper repeatedly makes is based on a deconstruction of the psychopathology of racial grief in order to understand that:

The problems of madness and misery, then, lie not inevitably in any inherent impairment of perception, emotion or conduct... Instead they are located in the contexts they inhabit, particularly in intolerant norms and the fetish for rationality. Once this epistemological tack is taken then warranted paternalism to those with psychological afflictions melts away (Pilgrim and Rogers, 2008:36)

It could be argued that paternalistic western forms of psychology, psychiatry and social work rely on 'intolerant norms and the fetish for rationality' and function as mechanisms of regulation and control (Adams, Dominelli, \& Payne, 2002; Dominelli, 1996; Hasenfeld, 1987; Jordan, 2004; Parker, 2014, 2018; Powell \& Khan, 2012; Rodger, 1988; Webb, 2000). The imperative is for Black women to understand their racial grief, as a symptom of the context of racism, which they are located in and call for a 'treatment' responses that tackle the social root of the problem. In other words, the call for Black feminist mobilization constituted by, and contingent upon, racial grief is as therapeutic as it is political. Indeed within the critical framework of the activism of Black feminism, the 'intolerant' norm of fragmenting the therapeutic from the political is contested; the therapeutic and political are integrated in a mutually constitutive relationship.

\section{Disconnections of Historical Amnesia}

Importantly, The Combahee River Collective Black Feminist Statement is as relevant in 2018, as it was forty-one years ago, such that, not to engage with its relevance is a loss in itself for contemporary Black feminism. The Black feminist, Audre Lorde warned of:

a historical amnesia that keeps us working to invent the wheel every time we have to go to the store for bread. We find ourselves having to repeat and relearn the same old lessons over and over that our mothers did because we do not pass on what we have learned, or because we are unable to listen. For instance, how many times has this all been said before? (1980:117)

The Combahee River Collective Black Feminist Statement represents an act of passing on what was 'learned' by the Black feminist members of the collective as a resource for 
contemporary feminist collectives and the women that configure these communal gatherings. This learning should be listened to; not because it will allow contemporary Black feminists to fast track past their inevitable struggles, but, because, important moments of contemporary resonance with The Combahee River Collective are important moments of connectivity. One essential form of connection is recognizing that '[c]ontemporary Black feminism is the outgrowth of countless generations of personal sacrifice, militancy, and work by our mothers and sisters'. (The Combahee River Collective, 1977: 262). Connection provides much needed nourishment in the occupation of the tension of simultaneously grappling, on the one hand, with internalized oppression 'planted deep within each of us, and which knows only the oppressors' tactics, the oppressors' relationships' (Lorde, 1980: 123), whilst on the other hand, striving for liberation from that very same oppression. Connection transforms the fragmentation, isolation and disintegration that are symptomatic of the racial grief. Notions of mourning and melancholia need to account for the fact that within the context of racism, racial grief can never know rest. Lorde, explains that:

Black women and our children know the fabric of our lives is stitched with violence and with hatred, that there is no rest. We do not deal with it only on the picket lines, or in dark midnight alleys, or in the places where we dare to verbalize our resistance. For us, increasingly, violence weaves through the daily tissues of our living-in the supermarket, in the classroom, in the elevator, in the clinic and the schoolyard, from the plumber, the baker, the saleswoman, the bus driver, the bank teller, the waitress who does not serve us. (1980: 119)

\section{The Master's Tools Will Never Dismantle The Master's House (Lorde, 1979)}

This section begins with an excerpt from a poem by Cooper (2006:19), which explicitly locates the impact of racial grief within the context of the 'violent incarnations' of the earth. Here the condition 'that she was tired' is framed as a mental disorder but as a symptom of 'tedious repetitions'. The point here is that any form of treatment or psychological intervention to alleviate the symptoms should not replicate the cause of the symptoms.

No

it was not her illness

whether of the mind or flesh

it was just that she was tired

tired of earth and its tedious repetitions

tired of earth and its violent incarnations
It could be argued that any form of Eurocentric clinical psychology, social work or psychiatric approaches to the symptoms of psychic trauma produced in the context of racism are both implicated in and inevitably (re)produce racism. For example, less than 200 years ago, the following mental disorders were recognized as legitimate: 'Dysaesthesia Aethiopica' or the disease of lazy African people who avoid work and 'Drapetomania' or the compulsion to run away from slavery. In his seminal work The Souls of Black Folk, (published 1903) Du Bois asks, 'How does it feel to be a problem? (Du Bois, 2008: 7) and Ahmed picks up this question in her research blog Feminist Killjoy (Ahmed, 2014), stating, 'When you expose a problem you pose a problem. I have been thinking more about the problem of how you become the problem because you notice a problem. When exposing a problem is to become a problem then the problem you expose is not revealed' (February 17th 2014). Pertinent, here, is Audre Lorde's essay, The Master's Tools Will Never Dismantle The Master's House, where she asks, 'What does it mean when the tools of a racist patriarchy are used to examine the fruits of that same patriarchy? It means that only the most narrow perimeters of change are possible and allowable.' (1979: 110-111). It would seems that using 'the master's tools' to tackle the problem of racial grief positions the 'problem' of racism with the person suffering from racism. In the situation, where subjects are 'always already' interpellated (Althusser, 1971:33-34) and subject to the 'injurious interpellations'(Butler, 1997:104) of racism, racial grief has no beginning or end, the question is, how does this sit/fit with the dominant Eurocentric models of loss, proposed by Elisabeth Kübler-Ross (Kübler-Ross 1969; Kübler-Ross \& Kessler, 2005) or Collin Murray Parkes (Parkes et al. 2015; Weiss \& Parkes 1983)? Furthermore, why are 'the master's tools' of dominant Eurocentric models of psychology, psychiatry, psychoanalysis and social work, which are steeped in the legacy of colonial, imperialist, paternalistic ideology used to respond to Black women's 'talk about their feelings of craziness... [under] patriarchal rule' (The Combahee River Collective, 1977: 262)? Here is the response of The Combahee River Collective:

Black feminists often talk about their feelings of craziness before becoming conscious of the concepts of sexual politics, patriarchal rule, and most importantly, feminism, the political analysis and practice that we women use to struggle against our oppression. The fact that racial politics and indeed racism are pervasive factors in our lives did not allow us, and still does not allow most Black women, to look more deeply into our own experiences and, from that sharing and growing consciousness, to build a politics that will change our lives and inevitably end our oppression (1977: 262-3) 
In this excerpt, The Combahee River Collective name the multiple interconnected sources of their racial grief that serve as the impetus and logic for building a movement of liberation to combat the sources of fragmentary racial loss. Importantly, what is named is that the pervasive nature of racism inhibits Black women's capacity to look deeply into their own experiences and this, in itself, (re)produces and acerbates loss, manifest in:

- Black women feeling isolated, disconnected, fragmented and alone because of lack of opportunity or capacity for communal sharing experiences of racial grief.

- The loss of connection, communion and unity between Black women inhibits, consciousness of the machinations of racist, patriarchal rule within capitalism;

- The loss of the space and opportunity to develop Black feminist consciousness obstructs the development and utilization of Black feminist conceptual tools;

- The loss of sharing and growing consciousness between Black women (re)produces the 'dividing practices' (Foucault, 1975, 1982) or " individual-society" dualism' (Parker \& Spears, 1996:4) that situates Black women's feelings of craziness as an inherent pathological impairment.

The legacies of Black women's empowerment, including documents, such as The Combahee River Collective Black Feminist Statement, testify to the therapeutic political power of Black women's spaces of sharing and growing consciousness. The Combahee River Collective Black Feminist Statement reports that 'our Black women's style of talking/testifying in Black language about what we have experienced has a resonance that is both cultural and political' (1977:264). At the very least, it is incumbent upon professional disciplines of mental well-being, such as psychology, psychoanalysis, psychiatry and social work, to foreground critical race, Nigressence and Black feminist empowerment models that include 'Black women's style of talking/testifying' in their practices; not to do so is collusion with racist patriarchal systems of domination which produce the symptoms that these professional disciplines of mental health purport to treat (Cross, 1971, 1991; Helms, 1990, 1995; Hooks, 1993; White \& Parham, 1990; Worrell, Cross, \& Vandiver, 2001).

\section{The Combahee River Collective}

The Combahee River Collective was a Black feminist organization active in Boston from 1974 to 1980. The Combahee River Collective formed in response to the loss of inclusion, recognition, legitimacy and affirmation they encountered as Black feminist within white feminist and patriarchal Black liberation movements:

It was our experience and disillusionment within these liberation movements, as well as experience on the periphery of the white male left, that led to the need to develop a politics that was anti-racist, unlike those of white women, and anti-sexist, unlike those of Black and white men. (The Combahee River Collective, 1977:262)

It could be argued that disillusionment within movements of liberation is the catalyst for the contemporary response of dalit and adivasi women, who are sick of being positioned on 'the periphery' of feminism, and the catalyst for the mobilization of dalit and adivasi feminist movements (Anamika 2007; Chakraborty, 2003). The experience of dalit and adivasi women echo the experience of The Combahee River Collective in a call for a

shift prevailing practices of knowledge production that is, shifts in dominant expectations about (a) which actors can produce knowledge, (b) the methodology and content of knowledges produced, (c) the languages, genres and forms in which knowledges are produced, and (d) the manner in which new knowledges gain relevance as they reach different audiences and enable new kinds of socipolitical interventions (Sangtin Writers \& Nagar, 2006:150).

More generally, this paper calls for a 'shift prevailing practices of knowledge production' about how racial grief is thought about and acted upon. Moreover, this is a call for the empowerment of Black women, as experts on their racial grief, to be supported to put their knowledge to use to 'enable new kinds of socipolitical interventions'.

Barbara Smith (now aged 71 years, living in Albany, New York), a founder member of The Combahee River Collective, summarized the purpose and legacy of The Combahee River Collective, in the follow excerpt from an interview with Dianca London Potts:

Dianca London Potts: Last year was the 40th anniversary of the Combahee River Collective Statement, and this year marks the 41st anniversary of its publication. Can you talk a bit about what that collective meant to you?

Barbara Smith: It was very much the center of my life during the time that we were actually organizing in Boston in the 1970s... The [Combahee] collective was a lifeline for those of us who created it. We also always were involved in political organizing, so we were not just black feminists because we believed that black women should be treated equally and they 
deserve to have rights and black women were just as important as black men. We were black feminists because we believed we had to work to make change in the actual world, as opposed to just embracing a set of ideas. We were not doing any work at the time because we thought it would help to build a reputation. We were consciously building a black feminist movement. I'm very happy to have been one of the members and co-founders of the Combahee River Collective because when we were doing the work, including writing the statement, we certainly weren't thinking that 40 years into the future people would still be reading it, appreciating it, and using it as a catalyst for further social, economic, and racial and gender justice. (London Potts, 2018)

The building of a global twenty-first century Black feminist movement in the face of neoliberalism, neo-colonialism and advanced capitalism, including the anti-woman war on terror, is dependent on connectivity. Connections between the losses that bind women internationally have the potential to use globalization as a catalyst for transformation, but only if the differences between experiences of losses are acknowledged. To be clear, this is not about formulating the racial grief of women into a hierarchy of loss; rather it is about addressing unequal power relations between women. Furthermore, linkages between the losses, which constitute racial grief, need to be deconstructed. No loss is an island, no loss exists in splendid isolation, and, as such, any experience or examination of loss as a discreet atom is to produce further loss. The principle at work here is that approaches to fragmentation that replicate fragmentation (re)produces loss. Black feminist deconstructions of the intersectionality of loss are exposure of how the interconnections of loss 'become parts of the structured network of meaning' (Žižek, 1989:95).

The Combahee River Collective Black Feminist Statement offers a helpful unfolding of the complexities of negotiating solidarity in relations of loss and difference whilst resisting fractionalization:

Although we are feminists and Lesbians, we feel solidarity with progressive Black men and do not advocate the fractionalization that white women who are separatists demand. Our situation as Black people necessitates that we have solidarity around the fact of race, which white women of course do not need to have with white men, unless it is their negative solidarity as racial oppressors. We struggle together with Black men against racism, while we also struggle with Black men about sexism. (1977:264)

These complex negotiations of connection and separation have contemporary relevance, for example: within the family and communities of Black women in the 'Black Lives Matter' movement; within the family and communities of Black and Asian women living in the current Islamophobic war on terror; and, within the family and communities of dalit and adivasi women. In the face of limited or non-existence frameworks of support within mainstream state apparatus, perhaps, 'the only people who care enough about us to work consistently for our liberation are us' (The Combahee River Collective, 1977: 263). This is precisely, the reason why, Black feminist temporal and spatial linkages are imperative. Black feminist, connections between the historical and the global is an occupation of racial grief, which uses the situated knowledge of racial grief as a resource for transformation. Here, the term 'situated' is not a static, fixed position. In stark contrast, the term 'situated' refers to Black women 'using their experiences [of racial grief] as situated knowers' (Hill Collins, 2000: 19).

\section{Racial Grief is Intersectional}

The racial grief of Black women is intersectional. In the context of racism, the manifestation of fragmentation and disconnection is in the material and psychic conditions of poverty, unequal distribution of opportunity and denial of human rights. For example, the Black women in the The Combahee River Collective stated that 'We do not have racial, sexual, heterosexual, or class privilege to rely upon, nor do we have even the minimal access to resources and power that groups who possess anyone of these types of privilege have' (1977: 265).

Intersectionality, coined by Kimberlé Crenshaw in 1989, is 'the notion that identity is formed by interlocking and mutually reinforcing vectors of race, gender, class and sexuality' (Nash 2008:3). Thus, the production and (re)production of fragmentation in regard to loss, due race, gender, class and sexuality, is at the same time 'interlocking' and interconnected. Black women's 'intersectional experience is greater than the sum of racism and sexism' (Crenshaw, 1989:140). In short, under the critical Black feminist lens of the concept of intersectionality there is a refusal of reductionist addition and subtraction or hierarchical approaches to the racial grief of Black women. The theoretical, methodological and political lens of Intersectionality is a contestation of the fragmentation of Black women's experiences. The critical Black feminist lens of intersectionality would propose a reiterative referral and deferral of loss dynamic where loss is constituted of fragmentation and disconnection, and fragmentation and disconnection is constituted of loss, and this dynamic is multiple, simultaneous and interconnected. The critical Black feminist lens of intersectionality provides an 
alternative integrated approach to modalities of psychopathology based on separation, disconnection and fragmentation.

Contemporary feminist debates about the viability, constraints and relevance of intersectionality are dominated by a reductionist and fragmentary emphasis on identity categories. Questions such as: can the 'buzzword' (Davis 2008) 'intersectionality' be extended beyond race, class and gender, to incorporate all identity categories? Is intersectionality a methodology, conceptual tool or just an outdated idea? miss the crucial element of context, situation and condition that The Combahee River Collective understood and articulated back in 1977 (Ahmed, 2012; Bilge, 2013; Collins \& Bilge, 2016; Falcón \& Nash, 2015; Taylor et al. 2010). The word intersectionality is not in The Combahee River Collective Black Feminist Statement; however, it states that, 'the major systems of oppression are interlocking. The synthesis of these oppressions creates the conditions of our lives.' (1977: 261). Note the reference to systems, and conditions; in short, contemporary contestations about intersectionality would do well to re-read The Combahee River Collective Black Feminist Statement, and in particular, the emphasis that this historical Black feminist statement places on context. Indeed, as Nayak, Montenegro and Pujol (2018) demonstrate, intersectionality is more about context than identity and as such it possibly more in keeping with the principles of intersectionality to speak of 'contextual intersectionality' and 'situated intersectionality'. The idea of situated/contextual intersectionality is in keeping with the idea that racial grief is a product of the situated/contextual experience of racism. This is an example of the importance of resisting historical amnesia; the importance of the temporal linkages is between Black feminist scholarship and activism. It is an example of the importance of activating the connections between the past, present and future in Black feminist activism. Perhaps, the observation by the psychoanalysis and social worker Patrick Casement that subjectivity is 'shaped by past experience and a continuing tendency to see the present in terms of the past' (1985: 2) could be applied to activating the temporal connections between Black feminist movement builders.

\section{Conclusion: The Occupation of Racial Grief 'Can Never be Underestimated' (1977:266)}

The Combahee River Collective Black Feminist Statement makes it clear that loss was a motivating factor for Black women to join the collective: 'and every Black woman who came, came out of a strongly-felt need for some level of possibility that did not previously exist in her life'
(1977:265). However, and this is precisely why texts such as The Combahee River Collective Black Feminist Statement, and Audre Lorde's essay 'Eye to Eye: Black Women, Hatred and Anger' (Lorde, 1983) have such enduring relevance, the act of joining a Black feminist group is not a comfortable experience. Whilst, on the one hand, members of The Combahee River Collective experienced 'The overwhelming feeling that we had is that after years and years we had finally found each other' (1977: 267). On the other hand, the task of confronting manifold and interconnected racial loss is exhausting and terrifying because, 'Feminism is, nevertheless, very threatening to the majority of Black people because it calls into question some of the most basic assumptions about our existence' (1977: 266). In other words, calling into question the everyday tactics of the intersectional experiences of racialized oppression is painful and can feel like loss upon loss. It is imperative that these intimate, personal political struggles and interconnections of racial loss are explicitly named between Black feminists. When will we learn that vulnerability is strength? When will we trust that and sharing the residence of racial grief is not a place of shame or blame but an occupation of growth and, if we can allow it, if we can love enough, a place of transformation? Black feminist activism is an experience of 'success and defeat, joy and pain, victory and failure' (1977: 265). The Combahee River Collective speak about the fragmentation and linkages within Black feminist spaces due to class, caste, sexuality and political disagreements, which become entwined with, and produce, other multiple interconnected losses:

In the fall, when some members returned, we experienced several months of comparative inactivity and internal disagreements which were first conceptualized as a Lesbian-straight split but which were also the result of class and political differences. During the summer those of us who were still meeting had determined the need to do political work and to move beyond consciousness-raising and serving exclusively as an emotional support group. At the beginning of 1976, when some of the women who had not wanted to do political work and who also had voiced disagreements stopped attending of their own accord, we again looked for a focus. (1977:267)

The point is that the inevitable intersectionality of fragmentation and linkage, within Black feminist spaces and between Black feminists, is not some problem to get over or resolve. The point is that without fragmentation there would be no linkage and vice versa. Thus, the occupation of racial grief is a paradoxical catalyst for building a twenty-first century international intersectional Black feminist movement. 
The words of Audre Lorde, from her essay, 'Uses of the Erotic: The Erotic as Power' captures the power and joy of Black feminist collective, connective sharing:

the power which comes from sharing deeply any pursuit with another person. The sharing of joy, whether physical, emotional, psychic, or intellectual, forms a bridge between the sharers which can be the basis for understanding much of what is not shared between them, and lessens the threat of their difference. (Lorde, 1978: 56).

The imperative is that all approaches to the symptoms of fragmentation found within the condition of racial grief 'form a bridge between the sharers'. This is a refusal of theory and methodologies (and of course one constitutes the other) that (re)produce fragmentation as a psychopathology.

Open Access This article is distributed under the terms of the Creative Commons Attribution 4.0 International License (http://creativecommons.org/licenses/by/4.0/), which permits unrestricted use, distribution, and reproduction in any medium, provided you give appropriate credit to the original author(s) and the source, provide a link to the Creative Commons license, and indicate if changes were made.

\section{References}

Adams, R., Dominelli, L., \& Payne, M. (Eds.). (2002). Critical practice in social work. Basingstoke: Palgrave.

Ahmed, S. (2010). The Promise of Happiness. Durham: Duke University Press.

Ahmed, S. (2012). On being included. Durham: Duke University Press.

Ahmed, S. (2014). Feminist killjoy blog post Feb 17th 2014. https://feministkilljoys.com/2014/02/17/the-problem-of-perception. Accessed 05 May 2019.

Althusser, L. (1971). Ideology interpellates individuals as subjects. In P. du Gay, J. Evans, \& P. Redman (Eds.), Identity: A reader. London: Sage Publications Ltd.

Anamika. (2007). Feminist Poetics: 'As Kingfishers Catch Fire'. New Delhi: Research \& Publishing House.

Anzaldúa, G. (2007). Borderlands/La Frontera: The New Mestiza (3rd ed.). San Francisco: Aunt Lute Books.

Bhabha, H. K. (1994). The location of culture. London: Routledge.

Bilge, S. (2013). Intersectionality undone: Saving intersectionality from feminist intersectionality studies. Du Bois Review: Social Science Research on Race, 10(2), 405-424.

Boyce Davies, C. (1994). Black Women, Writing and Identity: Migrations of the Subject. London: Routledge.

Butler, J. (1997). The psychic life of power: Theories in subjection. Stanford: Stanford University Press.

Casement, P. (1985). On learning from the patient. New York: Routledge.

Chakraborty, U. (2003). Gendering caste through a feminist lens. Calcutta: STREE.

Cheng, A. A. (2001). The melancholy of race. New York: Oxford University Press.

Collins, P. H., \& Bilge, S. (2016). Intersectionality. Cambridge: Polity press.
Cooper, A. (2006). Copper woman and other poems. Toronto: Natural Heritage Books.

Crenshaw, K. (1989). Demarginalizing the intersection of race and sex: A Black Feminist critique of antidiscrimination doctrine, feminist theory and antiracist politics. The University of Chicago Legal Forum. Feminism in the Law: Theory, Practice and Criticism, 1989, 139-167.

Cross, W. E., Jr. (1971). The Negro-to-Black conversion experience: Toward a psychology of Black liberation. Black World, 20, $13-27$.

Cross, W. (1991). Shades of Black: Diversity in African-American identity. Philadelphia: Temple University Press.

Davis, K. (2008). Intersectionality as buzzword: A sociology of science perspective on what makes a feminist theory successful. Feminist Theory, 9(1), 67-85.

Dominelli, L. (1996). Deprofessionalizing social work: Anti-oppressive practice, competencies and postmodernism. British Journal of Social Work, 26, 153-175.

Du Bois, W. E. B. (2008). The souls of black folk. Oxford: Oxford University Press.

Falcón, S. M., \& Nash, J. C. (2015). Shifting analytics and linking theories: A conversation about the "meaning-making" of intersectionality and transnational feminism. Women's Studies International Forum, 50, 1-10.

Foucault, M. (1975). The birth of the clinic: An archaeology of medical perception (trans. A. M. Sheridan Smith). New York: Vintage.

Foucault, M. (1982). The subject and power. In H. L. Dreyfus \& P. Rabinow (Eds.), Michel foucault: Beyond structuralism and hermeneutics (2nd ed.). Chicago: University of Chicago Press.

Fox Piven, F., \& Cloward, R. A. (1979). Poor people's movements: Why they succeed, how they fail. New York: Vintage Books.

Freud, S. (1917). Mourning and Melancholia. The Standard Edition of the Complete Psychological Works of Sigmund Freud, Volume XIV (1914-1916): On the history of the psycho-analytic movement, Papers on Metapsychology and Other Works.

Gates, H. L. (1986). Writing race. In B. Ashcroft, G. Griffiths, \& H. Tiffin (Eds.), The post-colonial studies reader (2nd ed., pp. 216-218). London: Routledge.

Hasenfeld, Y. (1987). Power in social work practice. Social Service Review, 61(3), 469-483.

Helms, J. E. (Ed.). (1990). Black and White racial identity: Theory, research and practice. Westport, CT: Greenwood Press.

Helms, J. E. (1995). An update of Helms's White and people of color racial identity models. In J. G. Ponterotto, J. M. Casas, L. A. Suzuki, \& C. M. Alexander (Eds.), Handbook of multicultural counseling (2nd ed.). Thousand Oaks, CA: Sage Publications Inc.

Hill Collins, P. (2000). Black Feminist thought: Knowledge, consciousness, and the politics of empowerment (2nd ed.). London: Routledge.

Hooks, B. (1993). Sisters of Yam: Black women and self-recovery. Boston: South End Press.

Jordan, B. (2004). Emancipatory social work? Opportunity or oxymoron. British Journal of Social Work, 34(1), 5-19.

Kristeva, J. (1973). The system and the speaking subject. In T. Moi (Ed.), The Kristeva reader (pp. 24-33). Oxford: Blackwell Publishers Ltd.

Kübler-Ross, E. (1969). On death \& dying. New York: The Macmillan Company.

Kübler-Ross, E., \& Kessler, D. (2005). On grief and grieving: Finding the meaning of grief through the five stages of loss. London: Simon and Schuster UK Ltd.

London Potts, D. (2018). Barbara smith is still one of Feminism's most essential voices: Interview with Barbara Smith. 
https://www.shondaland.com/inspire/books/a17048702/barbarasmith-feminist-interview/. Accessed 31 May 2018.

Lorde, A. (1978). Uses of the erotic: The erotic as power. In A. Lorde (Ed.), Sister outsider: Essays and speeches. Trumansburg: The Crossing Press.

Lorde, A. (1979). The master's tools will never dismantle the master's house. In A. Lorde (Ed.), Sister outsider: Essays and speeches (pp. 110-111). Trumansburg: The Crossing Press.

Lorde, A. (1980). Age, race, class, and sex: Women redefining difference. In A. Lorde (Ed.), Sister outsider: Essays and speeches. Trumansburg: The Crossing Press.

Lorde, A. (1983). Eye to eye: Black women, hatred and anger. In A. Lorde (Ed.), Sister outsider: Essays and speeches. Trumansburg: The Crossing Press.

McDonald, P., \& Coleman, M. (1999). Deconstructing hierarchies of oppression and adopting a 'multiple model' approach to antioppressive practice. Social Work Education, 18(1), 19-33.

McIntosh, P. (1988) White privilege: Unpacking the invisible knapsack. In McIntosh, P. (ed). White privilege and male privilege: A personal account of coming to see correspondences through work in women's studies. The Wellesley College Center for Research on Women: Working Paper 189.

Minh-ha, T. T. (2011). Elsewhere, within here: Immigration, refugeeism and the boundary event. New York: Routledge.

Mohanty, C. T. (1984). Under western eyes: Feminist scholarship and colonial discourses. In C. T. Mohanty (Ed.), Feminism without borders: Decolonizing theory, practicing solidarity (pp. 17-42). Durham: Duke University Press.

Nash, J. (2008). Re-thinking intersectionality. Feminist Review, 89, $1-15$.

Nayak, S. (2015). The activism of black feminist theory: Race, gender and social change. Abingdon: Routledge.

Nayak, S., Montenegro, M., \& Pujol, J. (2018). Contextual intersectionality: A conversation. In S. Nayak \& R. Robbins (Eds.), Intersectionality in social work: Activism and practice in context. Abingdon: Routledge.

Oliver, K. (2001). Witnessing: Beyond Recognition. Minneapolis: University of Minnesota Press.

Parker, I. (2014). The crisis in modern social psychology, and how to end it. Abingdon/New York: Routledge.

Parker, I. (2018). Psy-complex in question: Critical review in psychology, psychoanalysis and social theory. Washington/ Winchester: Zero Books.

Parker, I., \& Spears, R. (1996). Psychology and society: Radical theory and practice. Chipping Norton: Pluto Press.

Parkes, C. M., Laungani, P., \& Young, W. (Eds.). (2015). Death and bereavement across cultures (2nd ed.). London: Routledge.
Pilgrim, D., \& Rogers, A. (2008). Socioeconomic Disadvantage. In R. Tummey \& T. Turner (Eds.), Critical Issues in Mental Health (pp. 23-40). Basingstoke: Palgrave Macmillan.

Powell, J., \& Khan, H. (2012). Foucault, social theory and social work. Romanian Sociology, 10(1), 131-147.

Rodger, J. J. (1988). Social work as social control re-examined: Beyond the dispersal of discipline thesis. Sociology, 22(4), $563-581$.

Seshadri-Crooks, K. (2000). Surviving theory: A conversation with Homi K. Bhabha. In F. Afzal-Khan \& K. Seshadri-Crooks (Eds.), The pre-occupation of postcolonial studies. Durham: Duke University Press.

Smith, B. (2017). Interview with Keenaga-Yamahtta Taylor. In K.-Y. Taylor (Ed.), How we get free: Black Feminism and The Combahee River Collective. Chicago: Haymarket Books.

Spender, D. (1980). Man made language. London: Routledge \& Kegan Paul.

Spivak, G. C. (1988). Can the subaltern speak? In C. Nelson \& L. Grossberg (Eds.), Marxism and the interpretation of culture. Basingstoke: Macmillan.

Taylor, K.-Y. (Ed.). (2017). How we get free: Black Feminism and The Combahee River Collective. Chicago: Haymarket Books.

Taylor, Y., Hines, S., \& Casey, M. E. (Eds.). (2010). Theorizing intersectionality and sexuality. Hampshire: Palgrave Macmillan.

The Combahee River Collective. (1977). A black feminist statement. In J. James \& T. D. Sharpley-Whiting (Eds.), The black feminist reader (pp. 261-270). Oxford: Blackwell Publishers Ltd.

Thiongo, N. W. (1996). Borders and bridges: Seeking connections between things. In F. Afzal-Khan \& K. Seshadri-Crooks (Eds.), The pre-occupation of postcolonial studies (pp. 119-125). Durham: Duke University Press.

Webb, S. (2000). The politics of social work: Power and subjectivity. Critical Social Work, 1(2), 1-2.

Weiss, R., \& Parkes, C. M. (1983). Recovery from bereavement. London: Basic Books.

White, J., \& Parham, T. A. (1990). The psychology of Blacks. New York: Prentice Hall.

Worrell, F. C., Cross, W. E., Jr., \& Vandiver, B. J. (2001). Nigrescence theory: Current status and challenges for the future. Journal of Multicultural Counseling and Development, 29, 201-213.

Writers, S., \& Nagar, R. (2006). Playing with fire: Feminist thought and activism through seven lives in India. Minneapolis: University of Minnesota Press.

Žižek, S. (1989). The sublime object of ideology. London: Verso.

Publisher's Note Springer Nature remains neutral with regard to jurisdictional claims in published maps and institutional affiliations. 